\title{
Liggaamstaal in gebed: 'n Nuwe-Testamentiese perspektief
}

A B du Toit

\section{ABSTRACT}

Bodily posture in prayer: a New Testament perspective

The New Testament does not prescribe any specific bodily postures or gestures for praying. All three universal postures, viz that of standing, kneeling and prostration, are repeatedly mentioned in the New Testament documents without comment. Directives are, however, given on the spiritual attitudes which should influence bodily expression. In deciding on different options for today the importance of socio-cultural conventions should be kept in mind. In line with the New Testament and the early church fathers it can be considered to express humility, contrition and supplication by kneeling and/or bowing the head (while standing or sitting), and to praise God while standing erect, with or without uplifting of the hands.

Wanneer 'n mens Nuwe-Testamentiese spiritualiteit en die vormgewing daarvan in die gebed sou ondersoek, sou liggaamstaal, soos dit uitgedruk word in liggaamshouding, liggaamsaksies, gesigsuitdrukking en gebare ${ }^{2}$, sekerlik nie as dié fokuspunt uittroon nie. Tog is hierdie aangeleentheid nie onbelangrik nie. Die mens is immers volgens die Bybel 'n psigo-somatiese eenheid wat op liggaamlike wyse uitdrukking gee aan sy geestelike belewenisse. Hierdie onvervreemdbare aard van menswees moet ook in ons gebedsbeoefening tot uiting kom, in die sin dat gelowiges se liggaamshouding sinvolle uitdrukking behoort te gee aan hulle innerlike gebedsbelewenis. Reeds Tomas Akwinas het gesê: "...adoration should involve the body as well as the soul because every person is a composite creature who owes adoration with his or her whole being"3. Die simboliese belang van rituele mag geensins onderskat word nie: "It is through ritual that religions often express their deepest truths"4.

Tog is dit so dat daar vandag besonder min doelbewuste aandag aan liggaamstaal gegee word. Dikwels geskied ons keuses bloot intuitief of tradisioneel. Wat die erediens betref, is liturgiese slordigheid en ondeurdagtheid aan die orde van die dag. Kerkgangers doen meganisties mee aan geykte gebedshoudings en 
handelinge. Sommige stel vrae, maar kry min antwoorde. Moet ons staande, sittend, knielend of dalk plat op die bodem bid? Met oop of toe oë? Met gevoude hande of met opheffing van hande? Waarom bly kerkgangers in sommige gemeentes tydens die skuldbelydenis en sommige ander gebede sit, maar by ander staan hulle weer? Waarom moet mans staan, terwyl vroue bly sit? Waarom staan almal in sekere gemeentes met die danksegging na die Nagmaal? Hoe moet daaroor geoordeel word dat sommige kerkgangers met lofprysing hulle hande na God toe ophef, terwyl ander bloot hulle hande in eerbied vou? Die vrae vermeerder steeds. Wat persoonlike gebed betref, is dit uit die aard van die saak moeilik te beoordeel. Dit is egter ' $n$ ernstige vraag of ons as gewone gelowiges vir onsself genoegsame rekenskap gee van die ligaamshouding wat ons tydens gebed inneem.

Die vraag sou gestel kon word of die doelbewuste bespreking en beredenering van gebedshouding nie die gevaar inhou dat dit mense se gebedslewe sal inhibeer nie. Gebedsbeoefening behoort immers spontaan en vanuit 'n innerlike gedrewenheid te geskied. Sou 'n wetenskaplike analise 'n baie persoonlike en sensitiewe saak soos hierdie nie straks sy spontaneïteit en innigheid ontneem nie? Hierteenoor moet egter die volgende oorwegings geldend gemaak word:

1. Daar word reeds vir baie eeue oor verskillende aspekte van die gebed besin. Kerkvaders soos Ireneüs, Tertullianus, Origenes, Augustinus en vele meer het hulle spesifiek oor liggaams-aksie by gebedsbeoefening uitgespreek ${ }^{5}$. Dit val egter te betwyfel of hierdie uitsprake die kerklike gebedspraktyk geïnhibeer het.

2. Ook in spontane gebedsbeoefening mak Christene van sekere konvensies gebruik. Konvensionaliteit beteken nie noodwendig verstarring nie, maar die gevaar van verstarring is wesenlik. Besinning is noodsaaklik, juis om verstarring die hoof te bied.

3. Spontaneïteit is belangrik, maar ons moet versigtig wees om dit nie ten koste van ander belangrike gesigspunte te beklemtoon nie. Spontane gebedsbeoefening het altyd 'n sterk subjektiewe karakter en is geneig om individualisties te wees. Sodra 'n mens beweeg na groepsgebede, soos by die erediens, moet die individualistiese voorkeure plek maak vir konvensies en reëlings wat dit vir die groter groep moontlik maak om sinvol saam te aanbid. Daarom dra gemeentelike liturgieë 'n kollektiewe karakter waarin die kerklike usansie en die consensus van gelowiges gereflekteer word. 'n Mate van regulering en institusionalisering is inderdaad onvermydelik. Lawrence Cunningham beskryf hoe hy by geleentheid van 'n RoomsKatolieke erediens tydens die Onse Vader getref is deur die verskeidenheid van gebedsaksies onder gemeentelede: sommige gesinne en pare het mekaar se hande vasgehou; ander het hulle hande priesterlik omhoog gehef na God; nog ander se hande was eerbiedig in smeking saamgevou. Tog het almal sekere basiese, algemeen-aanvaarde en gebruiklike konvensies gehoorsaam: almal het byvoorbeeld 
tydens hierdie gebed gestaan: "Everyone observed the basic ground rules (nobody, for example sat through the prayer) and nobody used gestures that were in dissonance with what was expected of worshipping Catholics"6. Indien gebedsbeoefening dus nie net 'n spontane en individuele aangeleentheid is nie, maar ook ' $n$ saak vir die gemeenskap van die gelowiges, is voortdurende besinning oor so 'n wesenlike uitingsvorm van sy spiritualiteit onontbeerlik.

4. Ons moet ook in gedagte hou dat gebedshandelinge 'n sekere objektiewe karakter aanneem wat self beinvloedend en pedagogies werk?. Tipies hiervan is die Paasfeesritueel van die Joodse Pasga waar die kind vra na die betekenis van die ongesuurde brood, die bitter kruie ensomeer en hierdie elemente dan nie net uitdrukking gee aan bepaalde herdenkingsmotiewe nie, maar ook vormend werk ten opsigte van volgende geslagte. Dieselfde vind plaas met gebedshouding. Ons het in hierdie verband 'n heel interessante uitspraak van Augustinus waarin hy sy bevreemding te kenne gee oor die feit dat sekere gebedsaksies in werklikheid op hulle beurt sy innerlike belewenis versterk. Hy verklaar: "Ek weet nie hoe dit is dat, alhoewel hierdie bewegings van die liggaam nie kan plaasvind sonder dat 'n beweging van die gees hulle voorafgaan nie, wanneer hulle sigbaar en uiterlik gemaak is, daardie onsigbare innerlike beweging wat hulle veroorsaak het, self versterk word nie" (De cura pro mortuis 7$)^{8}$. Hierdie soort wisselwerking hoef egter nie te bevreem nie. Dit is eie aan alle simbole. Maar dan moet daardie simbole sinvolle konnotasies hêे?.

In die lig van bogenoemde oorwegings is dit goed en nodig dat vanuit ' $n$ breë perspektief (Ou-Testamenties, Nuwe-Testamenties, kerkhistories, sosiokultureel, dogmatologies en kerklik-prakties) oor hierdie onderwerp nagevors sal word. Indien uit so 'n breë ondersoek duidelike resultate na vore tree, kan dit as riglyne dien vir eredienste en selfs vir persoonlike gebede. Hierdie bydrae uit 'n hoofsaaklik Nuwe-Testamentiese hoek is dus slegs 'n fragment uit 'n veel breër vraagstelling.

\section{LIGGAAMSTAAL IN GEBED VANUIT DIE HOEK VAN DIE VERGELYKENDE GODSDIENSGESKIEDENIS}

In sy magistrale werk oor die gebed ${ }^{10}$ het die godsdienshistorikus Friedrich Heiler 'n oorsig gegee oor die verskeidenheid van gebedshoudings en -aksies in die verskillende godsdienste van die wêreld. Hy het bevind dat die sosiale hoflikheidskodes en in besonder die begroetingskonvensies van gemeenskappe die belangrikste voedingsbron en modelle vir die ontwikkeling van bepaalde gebedshoudings was ${ }^{11}$. Begroetingswyses en -gebare het uitdrukking verleen aan die sosiale gevoelens wat die begroetende teenoor die objek van sy begroeting 
gekoester het. 'n Onderdaan sou in diepe eerbied voor sy koning neerbuig om aan hom hulde te bewys. Netso sou die aanbidder voor sy godheid buig om hom te vereer. Vanweë die belangrikheid van Heiler se ondersoek word die kern van sy bevinding oor die onderskeie gebedshoudings en gebare hier kortliks saamgevat ${ }^{12}$ :

Wat liggaamshouding betref, gaan dit basies om drie variasies: eerstens die staande houding (die mees algemene), tweedens die knielende (ook baie gebruiklik) met hurk en sit as variante, en derdens die totale neerbuiging waarby kop en hande die grond raak (Engels: prostration), soos dit vandag nog by Moslemaanbidding tipies is. Hoewel laasgenoemde ook as voortgaande gebedshouding by verskillende groepe voorkom, het dit volgens Heiler egter meesal net as inleiding gedien, waarna die gebed knielend of staande voortgesit is. In plaas van deur "prostrasie" kon gebede egter ook voorafgegaan word deur liggaamsbuiging of die vooroorbuig van die kop. Soms is gebede interessant genoeg ingelei deur die liggaam na regs of links in die rondte te draai of selfs te spring. Laasgenoemde is bekend by die Trishagion van die Joodse Agtiengebed. Klemens van Aleksandrië (Strom VII 7:40) vertel dat die Christene sekere uitroepe aan die einde van hulle gebede bewegend verrig het.

Ten opsigte van gebare was die heel gebruiklikste die uitstrek van hande, met die handpalms na buite gekeer na die godheid toe. In Israel is die hande uitgestrek na God se woonplek, hetsy in die heiligdom of in die hemel. Gebede is in baie gevalle, en by geleentheid selfs by die Jode, begin, begelei en/of afgesluit met handgeklap. Onder die swart volkere van Afrika speel handgeklap 'n groot rol in gebede. Die aanraak van of slaan op die bors ( $L k$ 18:13) is nie net in Israel bekend nie, maar ook onder die Egiptenaars en Romeine. Volgens Heiler is die vou van die hande, wat ongetwyfeld die bekendste gebedshouding van die Christendom is, deur laasgenoemde van die Germane oorgeneem ${ }^{13}$. Hy wys daarop dat hierdie gebedsaksie reeds onder die Sumeriërs, in ou Indië en Tibet, asook onder die Japannese voorgekom het. Billerbeck vermeld dat die vou van hande in die vierde en vyfde eeue van ons jaartelling ook by die Jode aan te wys is ${ }^{14}$. Die eerste Christelike getuienis vir hierdie gebruik stam waarskynlik uit die vyfde eeu $\mathrm{nC}^{15}$.

Baie gebruiklik was die soen of aanraking van die altaar of godsbeeld. 'n Ander handeling was dié van ontbloting, byvoorbeeld deur die uittrek van sandale, skoene of selfs klere. Dit is vandag nog onder ons gebruiklik dat 'n man wanneer daar gebid word, of by betreding van 'n kerkgebou, sy hoed afhaal ${ }^{16}$. Ontbloting van die bolyf was ook 'n praktyk in sekere godsdienste. Selfs sakrale naaktheid het voorgekom, byvoorbeeld in die misteriegodsdienste, en dit leef in die magie voort tot vandag toe. In sekere gevalle was verhulling weer 'n gebedspraktyk. So is/was verskillende vorms van kopbedekking gebruiklik by Jode, Christene en Moslems.

Vergelyk ons die bostaande lys van gebedshoudings en gebare met dié in 
die Ou en Nuwe Testament, vind ons dat daar in die Bybel geen enkele unieke Bybelse gebedsaksie voorkom nie. Dieselfde geld van die Vroeë Jodedom. Israel, die Vroeë Jodedom en die Nuwe-Testamentiese Christendom het hulle gebedsgebruike met die omringende volkerewêreld gedeel. Dit was nie hulle gebedsaksies wat uniek was nie, maar die inhoudelike vulling van daardie aksies. Dit was hulle geloof, ons kan ook sê: die besondere aard van hulle Godsverhouding, wat uniek was. Wanneer meer spesifiek die Christene in die eerste eeue, soos blyk uit die afbeeldinge van die Orantes (=biddendes) in die katakombes, staande en met opheffing van hulle hande gebid het, was dit nie hierdie gebedswyse wat hulle van heidense bidders onderskei het nie, maar die feit dat hulle hulle in die Naam van Jesus Christus, hulle Verlosser en Here, tot die drie-enige God gerig het. Jode en Christene het dus nie gehuiwer om gebedsaksies van ander volke oor te neem as hulle dié sinvol kon aanwend om uitdrukking aan hulle eie gebedsbehoeftes te gee nie. Nie die ritus was die beslissende nie, maar die mite wat aan die ritus sy spesifieke vulling gegee het. Die enigste voorwaarde waaraan laasgenoemde moes voldoen, was dat dit as 'n betekenisvolle uitdrukking van die mite beleef kon word.

\section{LIGGAAMSTAAL IN GEBED IN DIE NUWE TESTAMENT}

Oor die geheel gesien kry gebedshouding sowel kwantitatief as kwalitatief min aandag in die Nuwe Testament. Al drie algemene gebedshoudings (vergelyk hierbo) kom in die Nuwe Testament voor. Meermale word beweer dat 'n staande houding die normale in die Nuwe Testament is ${ }^{17}$. Hierdie stelling mag korrek wees, maar is nie so vanselfsprekend nie. Bowendien sal dit versigtiger genuanseer en gemotiveer moet word.

In die Nuwe Testament word vier keer na 'n staande gebedshouding verwys. In Matteus 6:5 word van die "skynheiliges" gesê dat hulle daarvoor lief is om staande in die sinagoges en op die straathoeke te bid. Die participium éo moet hier as 'n aanduiding van liggaamshouding verstaan word. Dat Jesus nie die "skynheiliges" se liggaamshouding as sodanig kritiseer nie, blyk uit Markus 11:25 waar die tweede persoon praesens $\sigma \tau \eta \dot{k} \in \epsilon \epsilon$ van die dissipels se staande gebedsaksie gebruik word en Jesus dit sonder kritiek aanvaar. Die praktyk van 'n staande gebedshouding blyk ook uit die gelykenis van die Fariseër en die tollenaar. In albei gevalle word van 'n staande houding gewag gemaak (Lk 18:11,13). Weer eens word hierdie gebedshouding nie gekritiseer nie. Dit is die Fariseër se selfgerigtheid en hooghartigheid wat afgewys word. Die tollenaar staan immers ook.

In drie uit die vier gevalle hierbo genoem, gaan dit om voorbeelde uit die destydse Joodse wêreld. Hierdie getuienis vir 'n staande gebedshouding as die normale in die Jodedom word bevestig deur die materiaal wat Billerbeck byeen- 
gebring het ${ }^{18}$. Wat die vroeë Christene betref, beteken dit dat slegs Markus 11:25 die bewyslas daarvoor sou moes dra dat die eerste Christene by voorkeur staande gebid het. Maar ons het darem ook ander getuienis. Eerstens is dit nie onbelangrik nie dat die staande houding heel gebruiklik in die Ou Testament ${ }^{19}$ en die normale vir die destydse Jodedom was. Die Ou-Testamenties-Joodse erfenis was in vele opsigte die moederbodem vir die geloofslewe van die eerste Christene ${ }^{20}$. Ons weet van geen goeie rede waarom Nuwe-Testamentiese Christene nie ook die staande houding vanuit die Jodedom sou oorgeneem het nie. Hierby kom egter ook nog die getuienis van die kerkgeskiedenis. Hier was dit vir alle eeue die mees aanvaarde gebruik ${ }^{21}$. Verskeie kerkvaders, en in aansluiting by hulle ook die Sinode van Nisea, het selfs die knielende houding op Sondae en in die tydperk tussen Pase en Pinkster afgewys omdat dit afbreuk sou doen aan die feestelikheid van Christus se opstanding 22 . In die lig van hierdie oorwegings het die standpunt dat die staande houding in die Nuwe-Testamentiese kerk die gebruiklike was, inderdaad 'n sterk saak.

As dit alles gesê is, moet egter daarop gewys word dat die knielende aksie vergelykenderwys tog sterker in die Nuwe Testament figureer. Waar ons net vier verwysings na 'n staande houding in die Nuwe Testament kry, kom daar heelwat meer aanduidings van 'n knielende gebedshouding voor. Vir laasgenoemde word

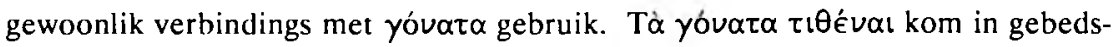
verband voor in Markus 15:19 (ironies), en is 'n voorkeurterm by Lukas: Lukas 22:41; Handelinge $7: 60 ; 9: 40 ; 20: 36 ; 21: 5$. In die Paulusliteratuur kry ons die

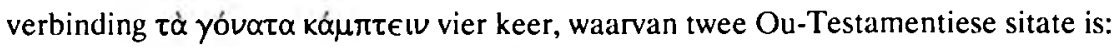
Romeine 11:4 (LXX); 14:11 (LXX); Filippense 2:10; Efesiërs 3:14.

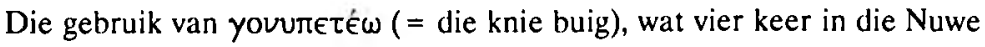
Testament voorkom, vra hier kortliks ons aandag. In Markus 10:17 (die vraag van die ryke) dui hierdie werkwoord bloot 'n respek-betonende buiging of knieval aan.

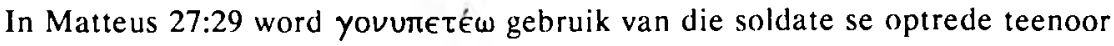
Jesus. Waar Markus berig dat die soldate (spottenderwys) die knie voor Jesus gebuig en Hom aanbid het, kry ons in die Matteuskonteks geen aanduiding van

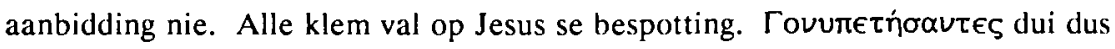
hier eerder 'n spottende knieval aan. Die oorblywende twee voorkomste, naamlik Matteus 17:14 en Markus 1:40, dui op 'n knielende of buigende houding wat aan 'n dringende versoek voorafgaan. In albei gevalle mag gebedsassosiasies wel meespeel. 'n Beslissing na enige kant toe bly egter blote raaiwerk.

Samevattend kan ons sê dat die Nuwe Testament meer as twee keer soveel verwysings na 'n knielende gebedshouding bevat as na die staande houding. Uiteraard hoef hierdie prominente aantal verwysings nog nie noodwendig die feitelike situasie in die vroeë kerk te reflekteer nie. Die moontlikheid is egter nie 
uitgesluit dat die knielende houding in die Nuwe-Testamentiese kerk net so gebruiklik of straks selfs meer gebruiklik as die staande houding was nie ${ }^{23}$.

Ons tref ook die derde algemene gebedshouding meermale in die Nuwe Testament aan. Vir "prostrasie" of neerval op die grond word veral die werkwoord $\pi i \pi \tau \omega$ gebruik. Soms funksioneer $\pi i \pi \tau \omega$ in hierdie betekenis sonder enige daaropvolgende voorsetsel saam met 'n gebedswerkwoord soos rpookuvéw: Matteus 2:11; 4:9; Openbaring 5:14; 19:4. In ander gevalle word voorsetsels gebruik soos émi, Évúmıv en ё $\mu \pi \rho \circ \sigma \theta \epsilon \nu$. In gevalle waar een van hierdie voorsetsels verbind word

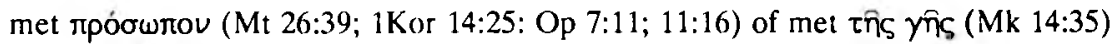

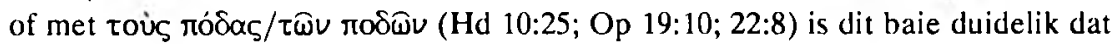
dit wel om daadwerklike "prostrasie" gaan en word diepe afhanklikheid of eerbied sterk beklemtoon. Dit is in hierdie verband opvallend dat alhoewel die werkwoord $\pi p o \sigma k v v e ́ \omega$ in die boek Openbaring ook dikwels van aanbidding van die dier gebruik word (13:4,8,12,15 ens), dit nêrens, soos met die aanbidding van God, aan "prostrasie" verbind word nie. Die skrywer van Openbaring evalueer hierdie neervallende gebedshouding by aanbidding van God in sy grootheid en verlossende goedheid $(4: 10-11 ; 5: 14 ; 19: 4)$ sterk positief.

Dit is belangrik om in hierdie verband ook nog kortliks aandag te gee aan enkele ander aspekte van die Nuwe-Testamentiese gebruik van die werkwoord

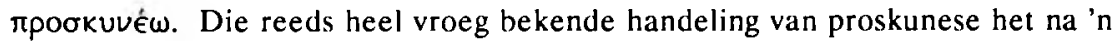
eerbiedig neerbuigende of neervallende aksie verwys ${ }^{24}$. Greeven is van mening dat

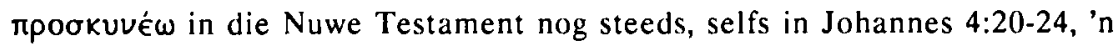
bepaalde liggaamsaksie aandui25. Sy standpunt is egter die gevolg van 'n diakroniese inlees in die teks vanuit die vroeëre liggaamsaksie van proskunese. Hierdie neerbuig of neerval-aksie speel in die Nuwe-Testamentiese gebruik van die werkwoord npookuvéw in gebedskonteks geen rol nie. Dit blyk uit die gevalle waar

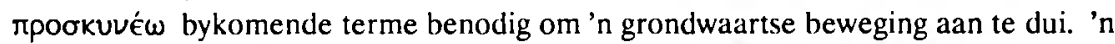

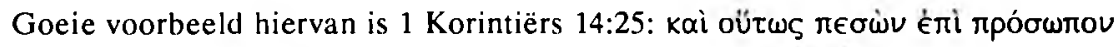

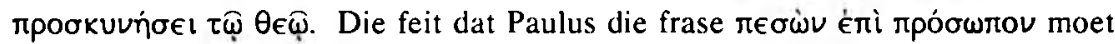

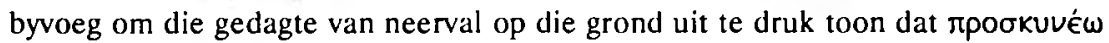
self dit nie meer doen nie. Dit beteken hier bloot aanbid. Hierdie feit word verder bevestig deur gedeeltes soos Matteus 2:11; 4:9; 28:9; Markus 15:19 en Handelinge

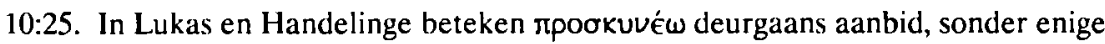
konnotasie van 'n bepaalde liggaamsaksie ${ }^{26}$. So ook in die Johannesevangelie. In Openbaring is die enigste uitsondering 3:9 (andersins 23 keer aanbid). Ek kan nie al die Nuwe-Testamentiese tekste hier aan die orde stel nie. Ek moet volstaan met die stelling dat ons geen enkele voorbeeld van 'n gebedskonteks in die Nuwe

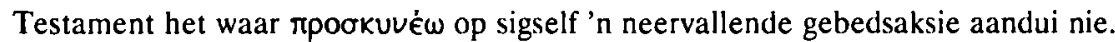
In sekere kontekste waar gebed nie ter sprake is nie, dui rpookuvé $\omega$ egter wel op 'n 
kniel- of neerval-aksie, byvoorbeeld Matteus $8: 2 ; 9: 18 ; 14: 33 ; 15: 25 ; 20: 20$; Markus 5:6; Op 3:9.

In die lig van bogemelde gegewens is dit duidelik dat ook die "prostrasie" 'n baie belangrike rol in die Nuwe Testament speel. Ons het selfs nog meer voorkomste van hierdie gebedsaksie as van die knielende een. Die groot probleem is dat ons nie mooi weet wat die verhouding van hierdie (diep afhanklike en/of verootmoedigende) aksie tot die knielende en staande gebedshoudings was nie. Was die "prostrasie" bloot 'n voorspel tot laasgenoemde, of is dit dwarsdeur die gebed gehandhaaf 27 ? Ons moet in gedagte hou dat die wisseling van gebedsaksies tydens gebed geensins vreemd aan gebedsbeoefening was nie.

Wat van die opheffing van hande in die Nuwe-Testamentiese kerk? Die enigste verwysing hierna is 1 Timoteus $2: 8$. In die lig van die groot rol wat die opheffing van hande in die ou Nabye Ooste ${ }^{28}$, in die Ou-Testamenties-Joodse wêreld ${ }^{29}$ en veral in die vroeë kerkgeskiedenis ${ }^{30}$ gespeel het, kan ons egter aanvaar dat hierdie handeling ook vir die Nuwe-Testamentiese Christene geensins iets vreemds was nie.

Uit die prominensie wat Lukas 18:13 daaraan verleen dat die tollenaar nie sy oë na die hemel wou opslaan nie, kan ons aflei dat sy optrede in kontras gestaan het tot wat volgens konvensie van hom verwag sou word. Die gebruik van oúdé voor

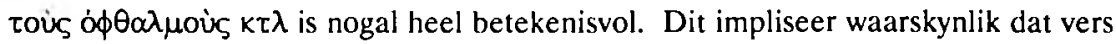
13a soos volg verstaan behoort te word: En hy het dit nie gewaag om selfs sy oë na die hemel op te hef nie, laat staan nog sy hande 31 . Hiervolgens was die opslaan van die oë nog gebruikliker as die opheffing van hande. Ons vind nog verskeie ander Nuwe-Testamentiese verwysings na die opslaan van die oë. In Markus 6:41 en sy parallelle gedeeltes (Mt 14:19 en Lk 9:16) word van Jesus gesê dat Hy met die vermeerdering van die brode biddend "opgekyk het na die hemel". In Markus 7:34 gebeur voor 'n genesing dieselfde. By die graf van Lasarus hef Jesus biddend "die oë op na bo" (Jh 11:41). Dieselfde is die geval in sy "hoëpriesterlike gebed" (Jh 17:1). Die opslaan van die oë het uiteraard gepaard gegaan met die ophef van die gesig na God. Hierdie houding word na alle waarskynlikheid ook by Petrus (Hd 10:9vv) veronderstel: Terwyl hy bid met sy oë na die hemel gerig, sien hy die hemelse visioen ${ }^{32}$.

Bevat die Nuwe Testament enige direkte of selfs indirekte voorskrifte oor wat Christene se liggaamshouding by gebedsbeoefening moet wees? Uit die voorafgaande behoort reeds duidelik te wees dat dit nie die geval is nie. Die Nuwe Testament verskil in hierdie opsig van die kerkvaders wat, soos ons reeds gesien het, by geleentheid wel voorskrifte gee. Dit gaan vir die Nuwe-Testamentiese skrywers, soos vir Jesus self, om iets veel diepers, naamlik om die hartsingesteldheid wat alle vorms van liggaamstaal behoort te bepaal. Op hierdie vlak vind ons wel verskeie 
Nuwe-Testamentiese riglyne.

Om die Nuwe-Testamentiese klem op hartsingesteldheid by gebedsbeoefening reg te waardeer sal dit goed wees om eers vooraf te onderskei tussen verskillende vlakke in die gebedsgebeure. Die heel eerste en diepste vlak is dié van gebedsgesindhede of ingesteldhede. In wisselwerking met die bepaalde omstandighede waarin bidders hulle bevind, kan hierdie ingesteldhede vervolgens sekere gebedsbehoeftes genereer. In die derde plek word gebedsbehoeftes uitgedruk in sekere gebedsuitinge of funksies. En hierdie gebedsuitinge vind vierdens gestalte sowel in innerlike of uitgesproke taal as liggaamstaal. 'n Ingesteldheid van skuldbesef skep byvoorbeeld 'n behoefte om daardie skuld voor God te bely. Hierdie behoefte word uitgedruk in 'n skuldbelydenis wat weer konkrete gestalte vind in gepaste woorde en liggaamstaal.

Die Nuwe-Testamentiese voorskrifte konsentreer op die dieper gebedsvlakke, en in besonder op dié van hartsingesteldheid, terwyl op die vierde vlak, dié van gebedshouding, 'n totale gebrek aan voorskriftelikheid, en daarom inderdaad 'n heerlike ruimheid en vryheid na vore tree. Dit gaan vir Jesus en die NuweTestamentiese skrywers veel eerder om die grondslag van ware aanbidding: die gebedsgesindheid. Ek wil vervolgens hierdie stelling aan die hand van enkele voorbeelde toelig.

As Jesus volgens Matteus 6:5-6 aan sy volgelinge opdrag gee om nie in die openbaar te bid om sodoende deur die mense gesien te word nie, maar eerder in die binnekamer, gaan dit om die noodsaaklikheid van 'n suiwer hartsingesteldheid, dié van volkome gerigtheid op God, sonder enige selfgerigte bymotiewe ${ }^{33}$. As Hy aan sy mense opdrag gee om nie met 'n "stortvloed van woorde" te bid soos die heidene nie, omdat hulle Vader reeds dadelik weet wat hulle nodig het (Mt 6:7-8), gaan dit om die kinderlike gesindheid van volkome Godsvertroue (=geloof). 'n Derde riglyn in Matteus 6 is dié van vergewensgesindheid (6:14-15).

Die klassieke formulering van die regte gebedsingesteldheid kry ons in Johannes 4:23-24, waar die grondreël vir alle ware aanbidding neergelê word. So

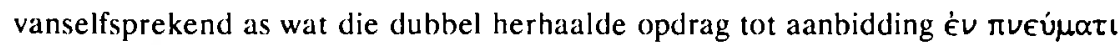
k $\alpha \grave{i} \dot{\alpha} \lambda \eta \theta \epsilon i \alpha$ mag klink, so moeilik is dit om sy presiese betekenis te bepaal. Raymond Brown sê van vers 23: "In vs 23 the particular point in question shifts from the place of worship (20-21) to the manner of worship"34. Hierdie stelling is basies korrek, maar daarmee is nog nie genoeg gesê nie. Die fokus val wel nou op die manier van aanbidding. Maar van hieruit beantwoord Jesus, binne die betrokke konteks, tog ook die lokaliteitsvraag. Die ware aanbidding, die aanbidding in die nuwe, Geesbedeling, sal juis vanweë sy geestelike karakter nie meer tot Jerusalem of Gerisim beperk wees nie, maar oral kan geskied. Sowel Schnackenburg ${ }^{35}$ as Brown ${ }^{36}$ het gelyk as hulle van die standpunt uitgaan dat $\dot{\epsilon} \nu \pi \in \in \dot{u} \mu \alpha \tau \iota$ op die Gees 
van God slaan ${ }^{37}$. En hulle is nog steeds reg as hulle beweer dat dit nie hier gaan om die kontrastering van 'n suiwer innerlike Godsaambidding teenoor uitwendige aanbidding nie ${ }^{38}$. Tog is met hierdie standpunte nog nie genoeg gesê nie. Die werking van die Gees sluit immers die menslike gees in. Die aanbidding "in die Gees" impliseer dat ons sal aanbid as mense wat deur die Heilige Gees beheers word, as mense wat "van Bo gebore is", nie meer as "vleeslike" mense, as mense "van onder" nie. Binne die konteks van hierdie hoofstuk, en in aansluiting by Johannes 3 , impliseer die Geesbepaaldheid warvan hier sprake is, aanbidding vanuit 'n radikaal-nuwe innerlike ingesteldheid wat deur die Gees daargestel word en wat 'n kwalitatief ander aanbiddingskwaliteit meebring. Die uitwendige aanbiddingsvorme word beslis nie uitgeskakel nie, maar die klem val daarop dat waaragtige aanbidding 'n Geesbepaalde kwaliteit moet besit. Een van die belangrikste aspekte van hierdie Geesbepaalde kwaliteit is die kindergesindheid. Dis nie toevallig dat Jesus hier twee keer van die aanbidding van God as "die Vader" praat nie ${ }^{39}$. Ons is hier baie naby aan Romeine 8, waar die Gees en gebed, die Vaderskap van God en die kindergesindheid op mekaar betrek word ( $\mathrm{Rm}$ 8:14-17,26-27). Opvallend genoeg is dit in Romeine 8 , by die gebruik van die woord $\pi \nu \in \hat{v} \mu \alpha$, nie altyd moontlik om te onderskei tussen die Gees van God en die menslike gees nie ${ }^{40}$. Dit is heeltemal moontlik dat év $\pi v \in u ́ \mu \alpha \tau \iota$ hier in Jh 4:23-24 ook 'n semantiese spel tussen God se Gees en ons menslike gees bevat ${ }^{41}$. In elk geval is die beslissende hier dat die aanbidding van die "ware bidders" ( $v 23$ ) nie meer bepaal word deur "vleeslike" oorwegings nie, maar deur dit wat eie is aan die Gees van God.

Die "waarheid" wat hier in Johannes 4:23-24 aan "Gees" verbind word, moet nie in die abstrakte Griekse sin verstaan word nie. Dit dui by Johannes op die nuwe werklikheid wat deur Jesus Christus geopenbaar is en waarby die gelowige ingeskakel word ${ }^{42}$. Ietwat sterk gestel sou ons kon sê die vereiste vir ware aanbidding is dat dit Geesbepaald en Christusmatig moet wees - Christusmatig in dié sin dat die aanbidding getrou moet wees aan dit wat in Christus geopenbaar is. In latere kerklike terme sou ons dit kon omskryf as "belydenisgetrou".

Die pasbesproke riglyn in Johannes 4:23-24 kan as 'n soort oorkoepelende karakterisering beskou word van wat die regte gebedsingesteldheid behoort te wees. Soos ons gesien het, sluit dit die ware kindergesindheid in. Ons het reeds in Matteus 6 drie meer spesifieke aspekte van die regte gebedsingesteldheid aangesny, te wete egte, onbaatsugtige Godgerigtheid, Godsvertroue (=geloof vgl Jk 1:6) en vergewensgesindheid. Die Nuwe Testament bevat ook nog ander riglyne wat ek nie hier kan behandel nie. Slegs die belangrikstes word neergestip: sondebesef (wat uitgedruk word in skuldbelydenis), eerbied en bewondering vir, en dankbaarheid teenoor God (wat uitloop op aanbidding, lofprysing en danksegging), afhanklikheid (uitgedruk in petisies) en die Christelike liefdesgesindheid (wat uitmond in 
voorbidding).

Ons vat ons bevindings saam:

1. In die Nuwe Testament kom 'n breë spektrum van gebedshoudings voor sonder dat negatiewe kommentaar op enigeen gelewer word. Sowel die staande, die knielende, as die neervallende houding word aanvaar. Die enigste gebedshouding wat nie in die Nuwe Testament voorkom nie, maar miskien wel by geleentheid in die $\mathrm{Ou}$ Testament ${ }^{43}$, is die sittende een. Ons kry wel by sekere kerkvaders polemiese opmerkings daarteen omdat dit 'n oneerbiedige ingesteldheid sou reflekteer. God word as die Koning beskou wat op sy troon sit, en dit pas sy dienaars om eerbiedig en diensbereid voor Hom te staan.

2. 'n Oorkoepelende tendens wat ons wel kan bespeur, is dat by geleenthede van die oorweldigende besef van God in sy grootheid en majesteit, maar ook van diepe verootmoediging en besondere smeking voorkeur verleen word aan gebeds-aksies met 'n afwaartse rigting, byvoorbeeld deur kniel, neerbuig of neerval. Hierby pas ook die afwaartse neig van die hoof en neerslaan van die oë44, soos in die geval van die tollenaar van Lukas 18 . Bockmuehl sluit hierby aan: "(A) kneeling position was assumed for particularly solemn, earnest or penitential prayers. The function of kneeling seems to be to express humility and prostration before God"45. Hiermee word die moontlikheid van uitsonderings natuurlik nie ontken nie. Ook 'n bidder wat sy hande en hoof omhoog na God opgehef het, kon op daardie wyse uitdrukking gee aan sy verootmoediging of smeking.

3. Die klem in die Nuwe Testament val nie op voorgeskrewe liggaamshoudings of gebare nie, maar wel op die motiverende en vormende kragte wat eersgenoemde bepaal. Daarom verskaf die Nuwe-Testamentiese skrywers, in aansluiting by Jesus Christus self, sterk riglyne ten opsigte van die vereiste gebedsgesindheid. Vanuit hierdie vertrekpunt openbaar die Nuwe Testament 'n besondere vryheid ten opsigte van gebedshoudings.

\section{RIGTINGWYSERS VIR VANDAG}

Om vanuit die Nuwe Testament rigtingwysers te probeer vind vir die regte liggaamshouding in gebed vandag, sy dit vir die erediens of vir persoonlike gebede, sal ons by die regte plek moet begin, naamlik die hartsingesteldheid van die biddende subjek. As liggaamstaal enige betekenis dra, en ek is oortuig daarvan dat dit ' $n$ belangrike funksie het, sal dit sinvolle gestalte aan gemelde ingesteldhede moet gee en die wisselende behoeftes wat met hulle verband hou. Sonder om dogmaties te wees moet ons dus vra na sinvolle maniere warop, volgens eietydse aanvoeling, aan behoeftes soos dié tot aanbidding, lofprysing, danksegging, skuldbelydenis, verootmoediging ensomeer gestalte gegee kan word. 
Ons het reeds vroeër gesien dat die liggaamlike vormgewing van gebedsbehoeftes deur sosio-kulturele aanvoeling bepaal word. Waar 'n sittende houding in teenwoordigheid van 'n sosiaal-meerdere byvoorbeeld as oneerbiedig ervaar word, sou dit ook as onvanpas vir die gebed beskou word. Hierdie soort aanvoeling kan wissel van geslag tot geslag en kultuurgroep tot kultuurgroep. Kerklik sal dus gevra moet word na watter houdings vandag in terme van ons eie sosiale konvensies en aanvoeling sinvolle uitdrukking aan ons gebedsingesteldhede en behoeftes kan gee en watter nie. Terselfdertyd sal ons in ag moet neem dat die Christelike tradisie self ook 'n vormende invloed op ons sosio-kulturele aanvoeling uitgeoefen het. Eintlik sou ons moes praat van 'n meervoud van kerklike tradisies, aangesien hierdie tradisies ook reeds verskillende aanvoelings gevestig het. Ook praktiese oorwegings het hier inspraak. Om byvoorbeeld voorsiening te maak vir 'n knielende houding vra heelwat meer finansiële insette. Ons het dus hier met 'n uiters komplekse werklikheid te make ten opsigte waarvan geen simplistiese antwoorde gegee kan word nie.

Aangesien die Nuwe Testament self geen voorskrifte in hierdie verband gee nie, sou ons moes vra of bepaalde Nuwe-Testamentiese gebedshoudings sekere voorkeure in terme van destydse konvensies weerspieël wat in terme van ons eie aanvoeling van huidige konvensies nog sinvol vir ons eie tyd kan wees.

Liggaamstaal in aanbidding is ' $n$ omvattende aangeleentheid. Dit is selfs meer as 'n staande, sittende, neerknielende of neervallende liggaamshouding met gepaardgaande hoof, oog en handaksies. Dit word uitgedruk deur ons totale menswees wanneer ons bid. Die menslike persoonlikheid omvat soveel moontlikhede, en ons konvensies het in hierdie opsig reeds sodanig afgeplat, dat die Bybelse gebedsgesindheid in talle houdings sinvolle uitdrukking sou kon vind. Dit geld ook vir die sittende houding in die erediens. In terme van ons huidige sosiale konvensie is dit nog so dat mense sal opstaan wanneer hulle eer wil betoon, byvoorbeeld by die verskyning van ' $n$ besondere gesagsfiguur of by die betreding van 'n kerkgebou. Tog word 'n sittende houding deur Westerlinge steeds minder as oneerbiedig ervaar. In hierdie sin bestaan daar geen beswaar teen 'n sittende houding as sodanig nie ${ }^{46}$, en sal die keuse tussen staan of sit of kniel waarskynlik van kerk tot kerk en gemeente tot gemeente wissel. Dieselfde variasiemoontlikheid geld by persoonlike of kleingroepgebede. Belangriker as die tipe houding is die innerlike ingesteldheid daaragter en dat daardie ingesteldheid in 'n positief beleefde houding weerspieël word.

Ons het egter wel gesien dat die Nuwe-Testamentiese skrywers oorkoepelend' $n$ afwaartse houding in die sin van neerkniel of totaal neerbuig, of van die afwaartse neig van die kop en neerslaan van die oë, as sinvolle uitdrukking van 'n ingesteldheid van intense aanbidding, van verootmoediging en smeking 
ervaar. Hierdie konvensie is universeel en tydloos, en sou daarom ook in ons eietydse ervaring sinvol wees. 'n Knielende houding sou in hierdie opsig baie sinvol wees. In die praktyk sal egter dikwels volstaan moet word met die afwaartse neig van die hoof by 'n staande of die eerbiedige vooroorbuig by 'n sittende houding. Dit sou goed wees as kerke en veral liturge dit in ag neem en leiding in hierdie verband gee, byvoorbeeld by skuldbelydenis in die erediens en by geleenthede van verootmoediging en besondere smeking. Aansluitend by die kerkvaders sou ons ook kon sê dat 'n staande houding weer besonder sinvolle uitdrukking kan gee aan gelowiges se behoefte tot lofprysing. Dit kan geskied met of sonder die uitstrek van hande na God toe. By 'n beslissing omtrent laasgenoemde sal die belewing van verskillende spiritualiteitstipes en tradisies ongetwyfeld 'n rol speel. In die lig van die ruim benadering van die Nuwe Testament tot liggaamstaal hoef hiervan werklik nie 'n geskilpunt gemaak te word nie. Met die reedsgenoemde praktiese voorbehoud wil ek dus samevattend aansluit by Markus Bockmuehl wat sê: "Should we kneel to pray? Yes, by all means let us kneel to ask earnestly for God's forgiveness, and to implore his help in conflict and adversity. And then, let us stand, too, to praise and worship him for our liberation"47.

Daarbenewens kan liturge ook in ag neem dat wisseling van gebedshoudings ${ }^{48}$, selfs tydens dieselfde gebedsgeleentheid, verandering in gebedsfunksie baie effektief kan weerspieël, byvoorbeeld by die oorskakeling van aanbidding na skuldbelydenis.

'n Laaste saak wat myns insiens aandag vra, is die liturgiese onderskeiding wat nog tussen die gebedshouding van mans en vroue gemaak word. Die gebruik dat eersgenoemdes by gebed staan, terwyl laasgenoemdes bly sit, kan op geen manier meer verantwoord word nie.

Die heel belangrikste is egter dat geen aanbiddingsaksie sommer maar net lukraak mag geskied nie. Voor die groot Koning van hemel en aarde pas stylvolle, innerlik deurleefde aanbidding.

\section{NOTAS:}

1 Effens gewysigde weergawe van referaat aangebied by 'n prakties-teologiese konferensie van die Teologiese Seminarium van die Baptiste op 6 September 1994 wat gehandel het oor liggaamshouding in aanbidding. Die woord "aanbidding" bied ruimte vir 'n groot verskeidenheid van verstaansmoontlikhede. Ek het myself beperk tot gebed as die beslissende aspek van aanbidding. Hierin sluit ek aan by die standaardwerk, Die Afrikaunse Woordeboek, wat as eerste betekenis van "aanbid" stel: "As goddelike wese vereer deur die gebed, ens". Hierdie definisie beperk aanbidding nie tot erediens-aanbidding nie. Wanneer ek in my bespreking geen doelbewuste onderskeid mak tussen liggaamshouding by 
erediensgebede en persoonlike gebede in die Nuwe Testament nie, geskied dit nie sonder rede nie. Ons moet die latere sterk kerklike onderskeiding tussen erediensgebed en persoonlike gebed nie op die Nuwe Testament terugkaats nie. Enersyds is gewone gelowiges se alledaagse lewe veel minder "sekulêr" beleef as vandag, en andersyds was die Nuwe-Testamentiese "erediens" veel minder "sakraal" as ons erediens. So is die Nagmaal byvoorbeeld gewoon aan huis tydens 'n gesamentlike maaltyd gevier wat grootliks met 'n gewone ete ooreengestem het. Op hierdie wyse is die sogenaamd "profane" lewe geheilig en die sogenaamd "heilige" in sekere sin gedesakraliseer. Vergelyk in hierdie verband A B du Toit, Der Aspekt der Freude im urchristlichen Abendmahl, Winterthur 1963, 103-149 en veral 104. Wat gebedshouding betref, kry ons ook by die Vroeë Jodedom geen aanduiding van 'n doelbewuste onderskeiding tussen gebede in die tempel, in die sinagoge, op straat of aan huis nie. In die reël is staande gebid, maar ook ander houdings was geoorloof (bv Dn 6:11). Vir bewysplase kyk endnoot 18.

2 Vergelyk F Heiler, Das Gebet. Eine religionsgeschichtliche und religionspsychologische Untersuchung, München/Basel 51969, 98.

3 Bewoording soos weergegee by L S Cunningham, "Gestures in prayer", Studies in Formative Spirituality 10 (1989), 186.

$4 \quad$ J Stern, "Modes of reference in the rituals of Judaism", Religious Studies 23 (1987), 109. Ten opsigte van die belang van liggaamstaal, kyk ook Cunningham, $a w, 182,185,187,192,194$.

$5 \quad$ Kyk byvoorbeeld by Cunningham, $a w, 185$.

6 Cunningham, $a w, 183$.

7 Stern, $a w, 115$.

8 Kyk veral G Matthews, Ritual and religious feelings, in: S M Cahn \& D Shatz (ed), Contemporary Philosophy of Religion, New York-Oxford 1982, 154-166.

9 Stern, $a w, 109-128$, bespreek die verskillende maniere waarop simbole kan refereer.

$10 \quad$ Kyk hierbo nota 2.

11 Heiler, $a$ w, 106-109.

12 Heiler, $a w, 100-105$.

13 Paul Volz, Die biblischen Altertümer, Stuttgart 1925, 245, is ook min of meer dieselfde mening toegedaan; dieselfde geld van J Döller, Das Gebet im Alten Testament, (ThSLG 21), sl 1974, 78-79.

14 P Billerbeck, Kommentar zum .Veuen Testament aus Talmud und Midrasch II, 
München 21956, 261-262.

15 So Döller, a $w, 79$. Hy verskaf ook verdere interessante besonderhede.

16 Vergelyk M Josuttis, Der Weg in das Leben, München 1991, 128-129.

17 Volz, $a w, 245 ;$ D R Ap-Thomas, "Notes on some terms relating to prayer", VT 6 (1956), 225.

18 Billerbeck, $a w$ I, 401, 852-853; II, 237,246,259; IV, 227. So onder andere ook J Elbogen (E L Rapp), art Gebet. II Im Judentum, $R G G^{3}$ II, 1217.

19 Döller, $a$ w, 73; M Bockmuehl, "Should we kneel when we pray?", Crux 26 (1990), 15.

20 So onder meer R T Beckwith, "The daily and weekly worship of the primitive church in relation to its Jewish antecedents", $E v Q 56$ (1984), 65-80.

$21 \quad$ F Heiler, $a w, 100$.

22 Kyk veral Bockmuehl, $a w, 16$.

23 Vergelyk die standpunte van F L Fisher, Prayer in the New Testament, Philadelphia 1964, 179; F Bradshaw, Daily prayer in the Early Church, Colchester-London 1981, 26-27, 64-65.

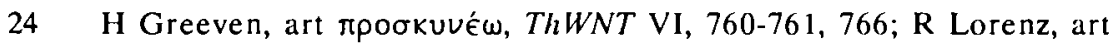
Proskynese, $R G G^{3} \mathrm{~V}, 641$.

$25 \quad A w, 764-766$.

26 Dit geld waarskynlik ook van Handelinge 10:25. Volgens die denke van die kaptein kon Petrus 'n soort hemelwese wees wat in aardse gestalte verskyn.

27 F Heiler, $a w, 100$-101, wys daarop dat eersgenoemde meer voorgekom het.

28 Heiler, $a w, 101-102$; Döller, $a w, 75-77$.

29 Döller, $a w, 75$; Billerbeck, $a w$ II, 261; Bradshaw, $a w, 18$ en voetnoot 94; M A Beek, God loven met het lichaam, in: Loven en geloven. Opstellen van collegas en medewerkers aangeboden aan Prof Dr Nic Ridderbos, Amsterdam $1975,204$.

$30 \quad$ Heiler, $a w, 102$; Bradshaw, $a w, 65$.

31 Kyk I H Marshall, The Gospel of Luke (NIGTC), Exeter 1978, 680.

32 Wat die destydse Jodedom betref, moet ons nie te veel maak van Billerbeck, $a w$ II, 246 se stelling dat die opslaan van die oë selde in die Jodedom vermeld word nie. Die rabbynse getuienis is beïnvloed deur die klem daarop 
dat bidders eerder in die rigting van die (gewese) tempel moet kyk as na bo.

33 U Luz, Das Evangelium nach Matthäus 1 (EKK 1,1), Neukirchen-Vluyn 1985, 325-327.

34 R E Brown, The Gospel according to John (I-XII) (AncB), London 1971, 180.

35 R Schnackenburg, Das Johannesevangelium (HTh KNT IV, 1), FreiburgBasel-Wien 1965, 471-472.

$36 A w, 180$.

37 Schnackenburg, ibidem; Brown, ibidem.

38 Schnackenburg, ibidem; Brown, ibidem.

39 Goed raakgesien deur Schnackenburg, ibidem.

40 Kyk A B du Toit, Romans 1,3-4 and the gospel tradition, in F van Segbroeck, C M Tuckett et al (eds), The four gospels 1992. Festschrift Frans Neirynck, Leuven 1992, 255.

41 In my pasgemelde artikel (kyk eindnoot 40), 255, wys ek op verskeie NuweTestamentiese tekste waar $\pi v \in \hat{u} \mu \alpha$ vermoedelik'n dubbelbetekenis het.

42 So tereg Schnackenburg, a w, ibidem.

43 Geleerdes verskil hieroor. Döller, $a w, 73-74$ betwis hierdie standpunt, terwyl Bockmuehl, $a w$, dit weer aanvaar.

44 Vergelyk ook Tertullianus, De oratione 17 , in verband met die neerslaan van die oë.

$45 A$ w 16 ; vergelyk ook 17 , eindnoot 13 , waar hy aantoon dat die kerkvaders dieselfde standpunt toegedaan was. Dit is juis om hierdie rede dat kniel op Sondae en in die tyd tussen Paasfees en Pinkster verbode was. Kyk ook Bradshaw, $a w, 64-65$.

46 Manfred Josuttis, $a w, 126-127$, doen selfs voorspraak vir die sittende houding. Hy begrond dit teologies: dié houding sou die aangewese een wees vir mense wat volledig op die Woord en geloof aangewese is.

$47 \quad A w, 17$.

48 Vergelyk Ap-Thomas, $a w, 226$, oor die waarskynlikheid hiervan in die Ou Testament. 